Houdyshell, M.E., Teaching as a career choice: A case study on the perceptions of emerging teachers

\title{
Teaching As a Career Choice: A Case Study on The Perceptions of Emerging Teachers
}

\author{
Michael E. Houdyshell, PhD.* \\ Assist. Prof., Florida Gulf Coast University \\ *Corresponding Author: mhoudyshell@fgcu.edu \\ Received : 2019-04-10 \\ Accepted : :2019-06-10
}

How to cite this paper: Houdyshell, M.E. (2019). Teaching As a Career Choice: A Case Study on The Perceptions of Emerging Teachers, Journal of Culture and Values in Education, 2(2), 21-37.

\section{Abstract}

As fewer and fewer students choose teaching as a career, the teaching profession struggles to understand how to recruit more students into the field, and prevent current teachers from leaving. Data shows the need for new teachers will continue to increase (Sutcher, DarlingHammond and Carver-Thomas (2016), while almost 70\% of schools reported at least one unfilled vacancy to begin the 2011-12 school year (Malkus, Hoyer, \& Sparks, 2015). Teacher preparation programs are also graduating fewer students into teaching (2016). This qualitative case study investigated the perceptions and beliefs of undergraduate students enrolled in an introductory course on teaching. Data from this case study is expected to confirm prior research on the reasons why students choose teaching as a profession, and help teacher preparation programs investigate if students' perceptions about becoming a teacher have changed. Results from this study support prior research on why students choose to become teachers, but also explores students views on how society views teaching, the continued salary gap with other professions, and the future of teaching.

Keywords: emerging teachers, new teacher recruitment, teacher preparation, teacher shortage

\section{Introduction}

The size of the teaching force in the United States is expected to grow at least until 2025 (Institute of Educational Sciences, 2015), however, the continued shortage of teachers to fill existing and new vacancies is not allowing districts to find qualified or interested candidates (Malkus, Hoyer, \& Sparks, 2015). They report that as far back as the 2011-12 school year, 68\% of schools in the United States had at least one unfilled teaching vacancy (2015). According to Sutcher, Darling-Hammond and Carver-Thomas (2016), the demand for new teachers is projected to plateau at about 300,000 in the 2017-18 academic year. Of the four factors they cite driving this emerging and current teacher shortage "based on the evidence available", one in particular is concerning for teacher preparation programs across the country-a decline in teacher preparation enrollments (Sutcher, et al., 2016, p. 37). With colleges and universities graduating fewer and fewer students with degrees in education prepared to teach in the 
Houdyshell, M.E., Teaching as a career choice: A case study on the perceptions of emerging teachers

classroom, the demand for new teachers coupled with higher teacher attrition rates (Sutcher, et al., 2016) will only continue exacerbating the issue of teacher shortages.

The $50^{\text {th }}$ annual Phi Delta Kapa (PDK) poll of the Public's Attitudes Toward the Public Schools, released in 2018, further highlights the issue of fewer teacher preparation enrollments. Of the over 1,000 parents randomly surveyed, $54 \%$ of respondents indicated they do not want their child to become a public school teacher, a majority response for the first time since this question was asked in 1969 (PDK Poll, 2018). In addition, as recently as 2015, 50\% of parents who were randomly surveyed said they believed that high achieving students should be recruited to become teachers (PDK Poll, 2015). While 46\% still support a teaching career for their child, that's down sharply from 2009 when it was 70\% and from the high of 75\% in 1969 when the PDK Poll was first launched (2018). Broken down by race, $77 \%$ of Hispanics in the survey favored their child working as a teacher vs. $51 \%$ for African-American parents, and only $40 \%$ of white parents (PDK Poll, 2018). This may reflect the fact that in today's classroom, nearly $50 \%$ are students of color vs. $82 \%$ of public school teachers that are white (Boser, 2014). This also may suggest that while for white respondents, becoming a teacher as a sign of economic upward mobility may not have the same impact as in the past, for African-American and especially Hispanic parents, teaching is still seen as a viable career path. In addition, because students of color are seen in a more positive manner by teachers of color and benefit from it academically and behaviorally (Partelow, Brown \& Johnson, 2014), it suggests those parents would also accrue some of the same benefits including viewing teaching as a positive career path for their children. In an open-ended question posed about why parents wouldn't want their child to become a teacher, the responses ranged from low salaries and benefits, followed by student behavior and lack of discipline (PDK Poll, 2018). Finally, white respondents without a college degree were also much less likely to favor their child becoming a teacher, $69 \%$ for males and 59\% for females respectively (PDK Poll, 2018). Clearly, a continuing qualified teacher shortage and decreasing support for becoming a teacher creates even more difficulties in addressing the future of teacher education preparation programs and the teaching profession.

\section{Literature on Emerging and Pre-service Teacher Attitudes to Becoming a Teacher}

With an ongoing teacher shortage and changing attitudes about becoming a teacher impacting the teaching profession, research over the last 10 plus years has illuminated why students choose to become teachers. Understanding these reasons may help teacher education preparation programs stem the tide of fewer students entering the teacher profession, and arrest the continued teacher shortage across the United States.

\section{Past Education Experiences}

For some students, traditional gender-related influences played a role in their decisions to become teachers. Bruinsma and Jansen's (2010) study of six first-year teachers highlighted the influences of gender-related influences including: growing up 'playing teacher'; female teachers as strong influencers while growing up; and the flexibility teaching offered in relation to having a family. In their study of current and former teachers, Howes and GoodmanDelahunty (2015) also reported many participants cited a "personal fulfillment incorporated a 
Houdyshell, M.E., Teaching as a career choice: A case study on the perceptions of emerging teachers

feeling of personal suitability for a teaching role which was often related to enjoyment of their own past school experiences" (p. 23). Additionally, they reported for a number of participants, "the idea of teaching had been a childhood dream" (p. 23). Wilson, Bell, Galosy, and Shouse (2004) also report the influence of former teachers is not to be discounted. Their research showed up to $32 \%$ of individuals deciding to enter teacher did so because of the influence of a former teacher (2004). In their study of Australian pre-service teachers, Manuel and Hughes (2006) also found a significant portion of participants reported having a mentor of a significant teacher who influenced their decision to become a teachers. Hennessy and Lynch's (2017) study of Irish pre-service teachers highlighted the significant influence that participants' "prior teaching and learning experiences...had on their decision to pursue a teaching career" (p. 123). While prior experience with a teacher or in an educational setting influenced the decisions of many pre-service teachers to pursue teaching, other factors also influenced this decision. In reviewing past empirical studies on international work exploring teacher choice, researchers also found prior teaching and learning experiences had "positive impact on decisions to become teachers" (p.265) for students in the United States, Australia, UK, and Ireland (Heinz, 2011; Heinz, 2013c; Heinz, 2015; Manual \& Hughes, 2006; Richardson \& Watt, 2005; Watt \& Richardson, 2007).

\section{Intrinsic and Extrinsic Factors}

For some pre-service teachers, the decision to enroll in a teacher-preparation program to become a teacher in some cases is driven as much or slightly less by the past influences of teachers, learning experiences, or more traditional gender-based view of teaching roles, and more by intrinsic factors including enjoyment of teaching, job satisfaction, and creativity. Additionally, intrinsic factors for becoming a teacher are sometimes combined with extrinsic factors such as status of the profession, levels of pay, and job security, but to a much lesser extent than when viewed separately. In König and Rothland's (2012) study of German preservice teachers, intrinsic factors such as the desire to work with children/adolescents was of significant importance influencing future teachers' motivation to become teachers. They also cite intrinsic motivation as positively influencing being successful during teacher preparation education (2012). Their research also shows some strong influence of extrinsic factors such as job security, as a predictor of what motivates students to enter a teacher-education program to become a teacher (2012), citing more "pragmatic views on motivations which teachers actually have" (p. 306). They conclude, understanding the "motivations for choosing teaching as a career are of high relevance..." (p. 306). Richardson and Roosevelt (2004) cite modeling recruitment programs like Teach for America as a way to recruit teachers. In their own experience, they conclude "...there is a segment of the college-going population for whom the intellectual challenges of teaching, in combination with the social commitment aspects and powerful human-relations component of teaching, are, if properly presented, a potential draw. A review of international empirical studies exploring student teachers' career motivations found intrinsic factors most influence students' choice to pursue a teaching career in countries like the United States, Australia, Germany, Norway, UK, Canada, China, Malaysia, and Turkey (Aksu, et al., 2010; Clarke, 2009; König \& Rothland, 2012; Heinz, 2015; Manuel \& Hughes, 2006; Su, et al., 2001; Watt \& Richardson, 2007). However, many of these same studies found extrinsic factors such as job security, hours, pay, and status, had some influence on the 
Houdyshell, M.E., Teaching as a career choice: A case study on the perceptions of emerging teachers

decisions of students to become teachers in countries like Australia, Canada, United States, Republic of Ireland, Turkey, Germany, and Norway but to a much lesser degree than intrinsic factors (Aksu, et al., 2010; Clarke, 2009; Heniz, 2011; Manuel \& Hughes, 2006; Richardson \& Watt, 2007; Tarman, 2012; Watt \& Richardson, 2007).

It was in this context that the purpose of this study was to investigate the attitudes, and perceptions of pre-service teachers and why they chose a major in teacher education. It also investigated what influences they may cite in their lives as reasons for wanting to become a teacher despite negative perceptions in society about the teaching as a profession. The research questions addressed from this case study are the following:

1. What do emerging or pre-service teachers perceive about becoming a teacher?

2. What influences in their lives helped them decide to become a teacher?

\section{Method}

A qualitative case study approach was used for this inquiry/study (Creswell, 2013; Yazan, 2015; Yin, 2014). A case study approach was used for this research because it lends itself to using detailed analysis and descriptors, in as single environment for this study (Baxter \& Jack, 2008). This case study was conducted in an introductory or foundational 3-credit course on teacher education offered by a college of education. Many teacher preparation programs require an entry-level or foundations course designed to introduce pre-service teachers to the field of teaching. This course often highlights the general themes and ideas about the teaching profession such as the history and theories of education, and contemporary issues of social, political, and legal contexts of schooling (Darling-Hammond, et al., 2005). Darling-Hammond, et al. (2005) also state these foundations courses are stronger if connected to some field experience in local schools, "it can support a much deeper understanding of educational purposes" (p. 192). However, because the landscape of teacher preparation programs in the United States is so diverse, there is "little centralized information about how teachers are prepared for their profession", including curriculum (National Research Council, 2010, p. 54). Consequently, no accurate data is compiled on how many teacher education preparation programs offer a similar course.

The introductory or foundations course used for this study is required by a college of education at a university in southern Florida, and is designed as a pre-requisite for all majors entering one of six teacher preparation programs. This particular college of education offers lower and upper-level programmatic structure of courses to complete one of the six teacher preparation majors. This introductory course is required to be completed by the end of their first year for first-time in college students. This particular course includes required field experience hours where students travel to assigned elementary, middle and high schools for observation time with current teachers and their students during the normal school day.

Participants from this specific introductory teaching course were gathered during the fall 2018 term, with 40 students enrolled. 35 of the students were female, and five were male. There were 23 Elementary Education majors, six Special Education majors, seven Early Childhood majors, one Secondary Math major, two Secondary Social Science majors, and one undecided major enrolled in the course. $84 \%$ of the students identified as White/Non-Hispanic, $11 \%$ as 
Houdyshell, M.E., Teaching as a career choice: A case study on the perceptions of emerging teachers

Hispanic, $1 \%$ as Asian-American, and $4 \%$ as unreported. Human subjects' approval was requested and deemed not necessary by the University IRB Office for this study. Data collected involved anonymous online small pre and post open-ended question surveys, end of term reflections and course assessments, and online discussion postings. Additionally, the researcher for the course has taught this course twice, and served as Assistant Dean for two years where he oversaw all recruitment efforts for new students into the teacher education programs for the College. The researcher views this study as an important investigation of the perceptions, thoughts, and influences about becoming a future teacher. As research has shown, the types of influences students receive often can help shape their choice of wanting to become a teacher (Heinz, 2015; König \& Rothland, 2012; Manuel \& Hughes, 2006; Richardson \& Roosevelt, 2004). Results from this case study are intended to be disseminated among teacher preparation programs across the United States, especially ones facing enrollment challenges in their teacher education majors.

The student participants for this study were chosen based on their enrollment in the introductory course on becoming a teacher. This type of sampling, called Purposeful Sampling, was used because all of the students were already in the course. The course runs over the span of about four months (one academic term) which allows ample time to gather data and refine questions, and it's less time consuming (Stake, 2005). All 40 students enrolled in the course were undergraduate students with less than 60 credit hours earned. 60 earned credit hours is required for admittance into any of the six teacher preparation programs offered by the College. As stated earlier, this is a required course to be taken by the end of their first year at the university as an education major.

To increase validity, this study employed triangulation during data collection, this included open-ended surveys, online discussion posts and in-class observations and discussions. Using triangulation during the study as a data collection method allows the researcher to create validity in the study with the use of multiple data sources (Hussein, 2009). The introductory course used for this case study was taught entirely face-to-face, meeting once a week for two hours and 45 minutes. In addition, much of the course content and work was accessed and submitted via the University's Learning Management System. During the class meetings and online, students were asked questions about influences of teaching, becoming a teacher, and the future of teaching. Students were given the opportunity to answer similar questions online either via discussions or anonymous survey links. This also allowed the researcher to expand on online responses during the face-to-face class sessions. The only text used for the course is called Teachers, Schools, and Society: A brief introduction to education (Sadker \& Zittleman, 2018). As stated earlier, the students were sent an anonymous online survey twice during the term, once at the beginning and again around mid-term. Discussion items about teaching were also posted throughout the term for student response. Finally, at the end of the term students were sent a Student Perception of Instruction (SPOI) course evaluation. This course evaluation is voluntary for all students in the course. Each instructor has the ability to add up to five additional and specific questions to this survey instrument. Five questions were added to the SPOI related to this research study (see Table 1). Again, an IRB was requested and deemed not necessary for this case study by the University Office of Research. All data collected for the study was anonymous or part of a larger class discussion. 
Houdyshell, M.E., Teaching as a career choice: A case study on the perceptions of emerging teachers

Table 1

Online Survey and SPOI Responses

\begin{tabular}{|c|c|c|}
\hline & Date Sent & \# of Responses \\
\hline First Online Survey & $8 / 24 / 18$ & 33 \\
\hline $\begin{array}{ll}\text { Second } & \text { Online } \\
\text { Survey } & \end{array}$ & $10 / 6 / 18$ & 5 \\
\hline SPOI Responses & $12 / 3 / 18$ & 14 \\
\hline
\end{tabular}

In reviewing data, all in-class discussion notes were reviewed after each class session. Responses to all online survey responses and the SPOI additional questions were also reviewed after each submission. Using a context analysis approach, the research is able to systematically categorize textual and conversational data in order to make sense of it (Forman \& Damschroder, 2007). The use of content analysis allowed the researcher to review online responses and probe further with additional questions or to adjust questions on future surveys which allowed each student to reflect multiple times throughout the course on the beliefs about becoming a teacher and respond at their own pace.

In this study, in-class discussions and online surveys were the preferred method of inquiry. This data combined with document analysis of all online responses including the SPOI, increased study validity through the use of data triangulation (Hussein, 2009). At the conclusion of the course, all in-class discussions, online survey responses, and SPOI course evaluation additional questions were investigated for themes using content analysis. The entire set of data created individual participant and study themes which were then analyzed for relevancy and presented in this case study.

In this study, the role of the researcher was as the instructor for the course where participants were enrolled. All data was collected, written, and analyzed by the researcher. The researcher attempts to present the findings and discussions as it's reported and coded without interjection of his own views. Any personal opinions and other findings outside of the coded information are presented in the discussion section.

To ensure validity and reliability of the study, the researcher utilized the following procedures: a) Data triangulation - All findings have been presented based on in-class discussions, online survey responses, and final course evaluation questions. After each in-class session, students were able to provide anonymous individual feedback to the researcher or as a posted online discussion question/response. This allowed students to amend any comments or provide further clarification for the researcher and for fellow students in the course. This was a 15week course which allowed for several conversations interactions with some participants maybe consider revising, sounds a bit ahem, and repeated attempts at clarification of data.

b) Direct quotations have been used where necessary and appropriate when presenting the findings. All data was reviewed for the reporting phase to reach common conclusions on findings, and possible codes and themes were then determined. 
Houdyshell, M.E., Teaching as a career choice: A case study on the perceptions of emerging teachers

\section{Results}

Analysis of the in-class discussion, online survey responses, and evaluation results, shows participants see the importance of early exposure to teachers in their lives in wanting to become a teacher. Many also cited family members who were either teachers or worked in education who encouraged them to become a teacher, but also sometimes conveyed realistic messages about how difficult it can be as a teacher. Regardless of their education program, participants described hearing negative messages about becoming a teacher either from others or society in general. Yet despite not always receiving encouragement from family or friends to become a teacher or hearing negative messages in society about teaching, there was an overwhelming sense of fulfillment or enjoyment when selecting teaching as a career. Additionally, participants described how society views teaching, how the importance of teaching as a career could be emphasized, and what the future of teaching looks like from their view as future teachers. The most identified themes or beliefs about becoming a teacher and teaching as a career were: becoming a teacher for reasons of enjoying the field or personal fulfillment, the difficult messages students hear about becoming a teacher, and what the future of teaching looks like and what participants look forward to most as future teachers.

Not surprisingly based on research on why individuals choose teaching as a career, intrinsic reasons for becoming a teacher were the most cited by participants. Research supports the idea that more students choose teaching as a career because of their interest in teaching (Aksu, et al., 2010; Clarke, 2009; König \& Rothland, 2012; Heinz, 2015; Manuel \& Hughes, 2006; Su, et al., 2001; Watt \& Richardson, 2007), and not just in the United States. The idea that the early life influence of a teacher or educator also can impact the decision to become a teacher is also supported by the literature (Hennessy \& Lynch, 2017; Manuel \& Hughes, 2006; Wilson, et al., 2004). However, participants were not isolated from hearing negative views about teaching as a career. As fewer and fewer parents and family members encourage teaching as a career choice for their children (PDK, 2018), participants are not immune from feeling the impact of how society views becoming a teacher. Even with a continued loss of individuals entering teaching and increasingly negative attitudes about becoming a teacher, participants still saw an encouraging future for teaching, despite the changes and challenges they would face ahead. While participants were certainly aware of the difficulties in being a teacher (as they have witnessed or heard), based on their responses, they were not necessarily planning to enter the field with an idealized view about their future profession. The literature supports how the practical application of teaching including issues like job security and intellectual stimulation, appeal to a certain segment of the college-age population with a nod to future enhancements like the use of technology (König \& Rothland, 2012; Richardson \& Roosevelt, 2004).

\section{Theme One: Intrinsic Value and Personal Influences}

When considering a career path, individuals are no less influenced by outside factors as they are internal motivations. When participants were surveyed about their reasons for becoming a future teacher, many mentioned a desire to work with children. "I love working with kids" was an often repeated response to this question. When probed for more detail, participants 
Houdyshell, M.E., Teaching as a career choice: A case study on the perceptions of emerging teachers

responded with 'I'm excited to work with children', 'I want to make a difference', and 'I know I for sure want to work with children'. At the end of the term when surveyed again about why students decided to become a teacher, similar responses were given if not a bit more pointed including 'I love being around kids and helping people succeed', 'I like working with young children', and 'I love working with kids and want to get them excited about learning'. Bruinsma and Jansen's (2010) study of pre-service teachers in the Netherlands focused on intrinsic and extrinsic adaptive motives (nineteen motives were used to indicate whether or not it had been important to their decision to become a teacher) for becoming a teacher. They found intrinsic adaptive motives such as a desire to feel competent, satisfy curiosity, or promote long lasting and effective engagement in a task, scored higher on intrinsic motives than on extrinsic motives (2010). An example of these motives was "working with children or adolescents" (Bruinsma \& Jansen, 2010, p. 190). Studies in the United States, Australia, Republic of Ireland, Slovenia, Turkey, Germany, Norway, and Canada show similar results in which intrinsic and altruistic motivations have a large influence on why students' choose teaching as a career including contributing to society and working with children/adolescents (Aksu, et al., 2010; Clarke, 2009; König \& Rothland, 2012; Heinz, 2015; König \& Richardson, 2012; Manuel \& Hughes, 2006; Su, et al., 2001; Watt \& Richardson, 2007).

Participants also cited influences of family, friends and especially former teachers as reasons for wanting to become a teacher. When asked more about why choosing to become a teacher or to list any influences, participants listed parents and other family members as influencers or having a family member who was already working as a teacher or in education. However, the most cited outside influencer to become a teacher in the lives of many participants were former teachers. Participants more often cited former teachers as major influencers on their decision to pursue teaching as a career. Example responses include '...good teachers that I have had in the past', 'My interest in becoming a teacher stemmed from my $8^{\text {th }}$ grade algebra teacher...he believed in me', 'Seeing how teachers have change and influenced my life so much', 'I had some extremely influential teachers growing up', 'So many teachers love their job and their enthusiasm inspired me', and finally '...since the third grade because I loved my teacher and wanted to be like her'. As one participant put it, 'in high school I was able to teach kindergarten and I LOVED IT'. Younger, Brindley, Pedder and Hagger (2004) reported that about one third of respondents in their study of UK pre-service teachers explained that their desire to become a teacher originated from their own positive learning experience in school. After intrinsic motivators, the importance of former teacher influences on the decisions of many participants choosing to become teachers can't be overstated. Research supports this result, as prior teaching and learning experience, and the influence of others including family members and especially former teachers have a strong influence on students pursuing teaching as a career (Akar, 2012; Heinz, 2011; Manuel \& Hughes, 2006; Su, et al., 2001; Watt \& Richardson, 2007).

\section{Theme Two: Choosing Teaching as a Career Path}

When deciding to become a teacher, participants were asked about what types of information or messages they received about becoming a teacher and from whom. Often these messages were from the very same individuals who were influencers in their lives about choosing teaching as a career; teachers and to a lesser extent guidance counselors. These messages 
Houdyshell, M.E., Teaching as a career choice: A case study on the perceptions of emerging teachers

ranged from simple reinforcements about teaching such as 'They have all really supported me', 'Teachers were supportive and helped me (in) how they could to get me where I am today' or 'I have been told that my personality would make me a great fit to be a teacher'. However, some participants cited a much stronger response from teachers specifically about their desire to become a future teacher, in some cases reinforcing the intrinsic motivators teachers observed. 'Many of my counselors have mentioned it to me because I was a big role model in school' and 'Some of my teachers and mentors in high school continuously told me that I should work with children...teaching can be incredibly rewarding and that choosing to be a teacher was the best decision they had made'. Research on students entering pre-service teaching to become a teacher supports how the influence of others, especially teachers, can have a positive impact on their decision (Akar, 2012; Clark, 2009; Heinz, 2013c; Howes, \& Goodman-Delahunty, 2015; Manuel \& Hughes, 2006).

In deciding to pursue a career as a teacher, participants commented on the positive messages and influencers they received from former teachers and others. They were also asked about how the importance of teaching as a career choice could be emphasized in our society outside of teaching. As the PDK survey indicated, for the first time since the survey was given in 1969, more parents do not wish for their children to become teachers (2018). This was not lost on many participants as they looked to the future when responding to this question, and commenting on the continued need for teachers, 'We always need teachers, no matter what. Without teachers we wouldn't be where we are today,', '...by emphasizing that teachers help future generations become successful,' and '...they (teachers) literally set everyone up for success or failure.' Participants also discussed how teachers can influence the children they are teaching, similar to the previous paragraph about the strong influence of former teachers on the decision to become a teacher. 'They (children) need great influences,' and '...emphasizing how much a teacher can influence a student.' Finally, participants connected back to theme one-the influence of intrinsic values on becoming a teacher when considering teaching as a career path. 'I believe our society looks down on teachers, however, without teachers there would be no society. If teachers teach their students with passion and inspire their kids, our society might change and respect teachers more.'

\section{Theme Three: The Future for Future Teachers}

Finally, participants were asked to reflect on the future of teaching and their own lives as future teachers. Many participants reported what they were most looking forward to in becoming a future teacher. Much of the responses dealt with helping children learn or making an impact in the classroom. Some participants also associated it with a deeper idea of learning and making an impact, similar perhaps to the impact made on some of them by former teachers. Words such as change, inspire, and impact were often used by participants. From the idea of 'Changing children(s') lives', '... being able to inspire them' or '... being able to make an impact on my students' to 'Helping shape and guide my students', 'To make students enjoy learning and accomplish their goals', 'Helping children achieve their highest potential' to a real focus on learning, 'Having kids learn to love learning and teaching them the importance of it' and 'Instilling in children from a young age the importance of learning'. These responses represent 
Houdyshell, M.E., Teaching as a career choice: A case study on the perceptions of emerging teachers

what Hennessy and Lynch's (2017) cite as the significant influence prior teaching and learning experiences with teachers have on students' decisions to become a teacher.

For participants in the study, when also asked about other types of messages they heard about becoming a teacher, many reported hearing negative information related almost entirely too low salaries. Fortunately, many that mentioned hearing about low teacher pay also were not as influenced and often referred back to choosing something they love to do or wanting to make a difference with responses including 'I don't care about the money as long as I am enjoying what I am doing', 'It's not about the money it's about helping our future generations gain a love for learning', 'The negative I constantly hear about is low pay, but this hasn't stopped me from pursuing this career because I am more focused on finding a career that I enjoy and where I can have an impact on others lives'. Finally, one participant perhaps summed it up best when they said 'The only negative I've heard is with the pay and it is not that big of a deal to me, I want to be a teacher to change lives, the pay is just a perk'. These responses align with research on altruistic or intrinsic motivators as strong influencers on wanting to become a teacher (Akar, 2012; Aksu, et al., 2010; Clark, 2009; Heinz, 2013c; König \& Richardson, 2012; Su, et al., 2001; Watt \& Richardson, 2007; Younger, et al., 2004). However, the participants responses are also contradictory yet encouraging, in relation to the research suggesting that in some countries (United States, Australia, UK, Republic of Ireland, Germany, Norway and Canada), extrinsic motivators, while much lower, do influence the decision to become a teacher (Aksu et al., 2010; Brookhart \& Freeman, 1992; Clarke, 2009; Heinz, 2013c; Manuel \& Huges, 2006; Watt \& Richardson, 2007). It might suggest intrinsic or altruistic motivators are becoming more of a factor influencing the decision to become a teacher in a new generation of future teachers.

Finally, participants were asked once at the beginning of the term and again at the end about the future of teaching and what it might look like. Responses from the first survey were a bit more pessimistic about the future, and responses from the second survey were more optimistic. During the first survey, participants cited issues of teacher respect and pay, and test scores as problems in the future. However, in the second survey with the same type of question about the future of teaching, participants had more hopeful responses about the teaching profession becoming more appreciated. 'It looks tough but worth it,' 'The future of teaching looks like students who actually want to learn...', and 'I think with all the people interested in making schools better, it looks like it has a great future.' One idea that dominated both surveys from the beginning and end of the term involved technology. Many participants cited the increasing use of technology to teach students in the classroom and online. 'Teaching in the future will involve double the amount of technology', 'I feel like there will start to be less classes with an actual teacher and more online', 'Lots of technology and apps to help the learning process...' and finally this remark from a participant, 'Teaching is always evolving. I believe technology now plays and will continue to play a large role in the classroom.' According to Stumpenhorst, in his book The New Teacher Revolution: Changing Education for a New Generation of Learners, he views technology as the "true linchpin in learning" (2015, p. 65). He believes "...the use of technology will not only benefit you as an educator but also the learning of your students" (2015, p. 71). It appears many of these emerging teachers also understand and feel that the use of technology will figure prominently in their future teaching careers. 
Houdyshell, M.E., Teaching as a career choice: A case study on the perceptions of emerging teachers

\section{Discussion and Conclusion}

Participants in this study were enrolled in a 3-credit required introductory course on the teaching profession. This course is not unlike similar courses found in teacher preparation programs across the country and is considered a common requirement for emerging teachers (Darling-Hammond, et al., 2005). With no solution to the continuing shortage of individuals wanting to become teachers (Malkus, Hoyer, \& Sparks, 2015), and demand for new teachers continuing to increase (Sutcher, Darling-Hammond and Carver-Thomas, 2016), it is important to understand what motivates individuals to pursue teaching as a career, and how to capture those motivations early on. Even in 2018, the motivations and influencers behind individuals wanting to become new teachers often mirror those found in research from over 10 years ago. However, it's also important to understand if those influencers might be shifting or in some cases have started to change with a new generation of future teachers. The literature supports understanding what motivates individuals to become new teachers in different countries around the world (Akar, 2012; Aksu, et al., 2010; Brookhart \& Freeman, 1992; Clarke, 2009; Heinz, 2013c; König \& Rothland, 2012; Maneul \& Hughes, 2006; Su et al., 2001; Watt \& Richardson, 2007; Younger et al., 2004). However, in several countries, including the United States, the research is not current, and hasn't necessarily kept pace with the changing face of individuals entering college. This case study was designed to first, validate and test outcomes from prior research on pre-service teachers, but also seek to understand if any outcomes had changed. With this in mind, this case study did in fact confirm that many of the intrinsic and altruistic motivators or influences found in the literature did still matter to participants in this case study. However, it also showed there might be a shift in at least one extrinsic motivator from past research - teacher pay.

According to the National Education Association (NEA) (2017), the average starting teacher salary in the United States for 2016-17 was $\$ 38,617$ per year. The average starting teacher salary in the state of Florida in 2016-17, where this case study was conducted, was \$37,405 annually (NEA, 2017). Most of the participants in this study who finish their teaching degree at the same university where the case study was conducted will go on to teach in Florida where their teacher certification is valid. This means many of these participants as new teachers will be receiving a smaller starting salary than the national average for new teachers. This is significant in that many participants cited teacher pay as not an important extrinsic influencer in their decisions to become new teachers. However, many of the same participants are not immune to data that shows that teacher pay lags behind many other professions when comparing salaries and compensation. According to data from the website Careerbuilder.com, the average starting salary for graduates in Engineering in 2018 was $\$ 66,521$, for business graduates it was $\$ 56,720$, and for Humanities and Social Sciences majors is was $\$ 56,688 / \$ 56$, 688 (Tarpey, 2018).

Salary issues remain a key issue for new and continuing teachers. Carver-Thomas and DarlingHammond's report (2017) on teacher turnover listed teacher compensation as one of the key factors associated with teacher turnover. In this case study, when asked about how the importance of teaching as a career choice could be emphasized in our society (United States), 
Houdyshell, M.E., Teaching as a career choice: A case study on the perceptions of emerging teachers

increasing teaching salaries was still the most frequent response from participants. While these future teachers from the case study were not as motivated extrinsically by salary as in other research, participants are not immune to the ongoing issues of low teacher pay across states, and how the work of teaching is not properly compensated in the view of how to decrease teacher attrition (2017). Carver-Thomas and Darling-Hammond cited addressing early teacher attrition as critical to stopping the country's continuing teacher shortage crisis (2017). Teacher attrition is two times what it is in other countries such as Singapore, Finland and Canada (2017). Carver-Thomas and Darling-Hammond (2017) reported that it can cost as much as $\$ 20,000$ for a district to replace a teacher who leaves. Creating better compensation for new and current teachers as a way to not only attract but also retain teachers, is supported by data from this case study, and research in the field.

While this case study of emerging future teachers was conducted at a university in the United States, it has broader implications among other countries also struggling with teacher shortages and how to attract more students into the teaching profession. Much of the research cited in support of the data from this case study was from countries other than the United States, including Norway, Canada, the Republic of Ireland, Turkey, Germany, the United Kingdom, and Australia (Akar, 2012; Brookhart \& Freeman, 1992; Clarke, 2009; Goodson, 2003; Heinz, 2013c; König \& Rothland, 2012; Manuel \& Hughes, 2006; Watt \& Richardson, 2007). The data from the case study indicates enough similarity in how students from the United States feel about becoming teachers with their counterparts in other countries, regardless of differences in educational policies, school structure, and teaching requirements. Many of the studies about motivating influencers for students choosing to become teachers are between 5-10 years old, which means countries are probably still grappling with how to attract students into the teaching profession, teacher shortages, and how to retain teachers.

As this was a small sample from a single case study at an institution in the United States, a limitation of the study is in the sample size. As described in the previous paragraphs, while the sample was small, the findings in many ways do mirror research on the same topic in other countries even if many of the studies are becoming dated based on when the research was conducted. While the results could be generalized across different countries, individual educational systems in other countries does present a challenge in using too broad of a stroke with the data to make sweeping declarations about what students are thinking when they choose to become teachers. It was also not a racially diverse sample (as represented by $84 \%$ of participants identifying as white), and there were no questions regarding how becoming a teacher might be influenced by one's race or ethnicity, so it's hard to determine if this is a factor or not in the decision to become a teacher. Only two studies looked at minority teacher candidates and inequalities as a motivating factor in becoming a teacher (King, 1993; Su, 1997). They were both from the United States, and found that some minority teacher candidates believe that teaching can contribute to the betterment of society $(1993 ; 1997)$.

A second limitation stems from when these participants were part of this case study. All of the participants were in the their first year of university, with for most, involves another three years of course work, internship, and mandatory state testing before graduating with a degree allowing them to be eligible to teach. As is the case for many college-age individuals, influences 
Houdyshell, M.E., Teaching as a career choice: A case study on the perceptions of emerging teachers

and motivations can occur at any point during their university studies, which have the potential to alter how they feel about career or major choices. As the case study was conducted with participants in an introductory level course, their motivations and influences can change over time as they mature and develop their identities. It may mean issues such as salary and career prestige while not important initially, can have more of an influence by the time they are ready to graduate. It would be important to conduct a similar study on career motivations and influences with these same students when they are much further along in their teacher preparation to interpret any changes in attitudes or beliefs about choosing teaching as a career. A final limitation involves the course used to conduct the case study. The course is viewed as an introductory course for students wishing to become future teachers. This would suggest that many of these participants are enrolled in the course with similar attitudes about becoming a teacher, and have perhaps already negotiated through the same issues that study cites, namely issues of becoming a teacher, influences on that decision, and how the future of teaching is viewed. It suggests, perhaps a more ideal time to study emerging teacher attitudes is earlier in the scholastic career, before entering university when students are often still considering career options in the midst of influences and experiences that may help shape those decisions.

\section{Implications}

The results of this study show that even with changes in how we view decisions about career choice, for a new generation of emerging teachers, what motivates them to choose teaching as a profession, and what influences those decisions hasn't changed. It is still largely dependent on internal and altruistic motivations (helping others learn, working with children/adolescents), and influences of former teachers and prior teaching experiences. In addition, it also showed that while salary and compensation are not the main drivers behind decisions to become teachers, it still matters, and will continue to matter until the teaching profession is viewed at least in the United States, with increased admiration and the compensation rises in accordance. Additionally, with a specific nod to the influence of former teachers on career choice, the field of teaching can't sustain itself let alone flourish if the profession does not self-promote, and actively recruit students in high school or younger to become teachers through the use of information about the benefits of teaching but more importantly from current teachers. Teachers must convey the message that teaching is a career choice that while has its limitations like any professional field, also has many benefits that appeal to the intrinsic motivators inside students who want to work with children or adolescents, and have a positive and affirming role model in their classroom - a teacher. As an individual who used to recruit high school students to become future teachers, so often teachers of many of these students use negative comments to describe the teaching profession. This amounts to unnecessary self-inflicted damage, in which students considering career choices are receiving negative messages about becoming a teacher from a very important influencer in their lives - a teacher. 
Houdyshell, M.E., Teaching as a career choice: A case study on the perceptions of emerging teachers

\section{References}

Akar, E. O. (2012). Motivations of Turkish pre-service teachers to choose teaching as a career. Australian Journal of Teacher Education, 37(10). 66-84. https://dx.doi.org/10.14221/ajte.2012v37n10.7

Aksu, M., Demir, C. E., Daloglu, A., Yildirim, S., \& Kiraz, E. (2010). Who are the future teachers in Turkey? Characteristics of entering student teachers. International Journal of Educational Development, 30, 91-101. https://doi:10.1016/j.ijedudev.2009.06.005

Baxter, P. \& Jack, S. (2008). Qualitative case study methodology: Study design and implementation for novice researchers. The Qualitative Report, 13(4), 544-559.

Retrieved from http://nsuworks.nova.edu/tar/vol13/iss4/2

Boser, U. (2014). Teacher diversity revisited: A new state-by-state analysis. Washington, D.C.: Center for American Progress.

Brookhart, S. M. \& Freeman, D. J. (1992). Characteristics of entering teacher candidates. Review of Educational Research, 62, 37-60. http://doi:10.3102/00346543062001037

Bruinsma, M. \& Jansen, E. P. (2010). Is the motivation to become a teacher related to preservice teachers' intentions to remain in the profession? European Journal of Teacher Education, 33(2), 185-200. https://doi.org/10.1080/02619760903512927

Carver-Thomas, D. \& Darling-Hammond, L. (2017). Teacher turnover: Why it matters and what we can do about it. Palo Alto, CA: Learning Policy Institute. Retrieved from https://learningpolicyinstitute.org/product/teacher-turnover-report

Clarke, M. (2009). Choosing post-primary teaching as a career: Perspectives from the Republic of Ireland. In S. Drudy (Ed.), Education in Ireland: Challenge and change (168-192).

Dublin, Ireland: Gill \& Macmillan.

Creswell, J. W. (2013). A case study. Quality inquiry and research design: Choosing among five approaches ( $3^{\text {rd }}$ ed.). Thousand Oaks, CA: SAGE Publications, Inc.

Darling-Hammond, L., Banks, J. Zumwalt, K., Gomez, L. Gamoran Sherin, M., Griesdorn, J., \& Finn, L. (2005). Educational goals and purposes: Developing a curricular vision for teaching. In L. Darling-Hammond \& J. Bransford. (Eds.), Preparing teachers for a changing world: What teachers should learn and be able to do (169-200). San Francisco: Jossey-Bass.

Forman, J. \& Damschroder, L. (2007). Qualitative content analysis. In L. Jacoby \& L. A. Siminoff (Eds.), Empirical methods for bioethics: A primer, 11. 39-62.

doi:10.1016/S1479-3709(07)11003-7 
Houdyshell, M.E., Teaching as a career choice: A case study on the perceptions of emerging teachers

Goodson, I. (2003). Professional knowledge, professional lives: Studies in education and change. Maidenhead, United Kingdom: Open University Press.

Heinz, M. (2015). Why choose teaching? An international review of empirical studies exploring student teachers' career motivations and levels of commitment to teaching. Educational Research and Evaluation, 21(3). 258-297. https://doi.10.1080/13803611.2015.1018278

Heinz, M. (2013c). Why choose teaching in the Republic of Ireland? -Student teachers' motivations and perceptions of teacher as a career and their evaluations of Irish second-level education. European Journal of Educational Studies, 5, 1-17.

Heinz, M. (2011). The next generation of teachers: Selection, backgrounds and motivations of second-level student teachers in the Republic of Ireland (Unpublished doctoral dissertation). National University of Ireland, Galway, Ireland.

Hennessy, J. \& Lynch, R. (2017). "I chose to become a teacher because." Exploring the factors influencing teaching choice amongst pre-service teachers in Ireland. Asia-Pacific Journal of Teacher Education, 45(2), 106-125. https://doi.10.1080/1359866X.2016.1183188

Howes, L. M. \& Goodman-Delahunty, J. (2015). Teachers' career decisions: Perspectives on choosing teaching careers, and on staying or leaving. Issues in Educational Research, 25(1), 1835. Retrieved from http://www.iier.org.au/iier25/howes.html

Hussein, A. (2009). The use of triangulation in social sciences research: Can qualitative and quantitative methods be combined? Journal of Comparative Social Work, 4(1). 1-12. Retrieved from http://journal.uia.no/index.php/JCSW/article/view/212/147

Institute of Educational Sciences, National Center for Educational Statistics (2015). Digest of Educational Statistics (NCES 2016014). Washington, D.C.: U.S. Department of Education.

King, S.H. (1993). Why did we choose teaching careers and what will enable us to stay?: Insights from one cohort of the African American teaching pool. The Journal of Negro Education, 62(4). 475-492. https:// doi:10.2307/2295518

König, J. \& Rothland, M. (2012). Motivations for choosing teaching as a career: effects ongeneral pedagogical knowledge during initial teacher education. Asia-Pacific Journal of Teacher Education, 40(3). 289-315. https://doi.10.1080/1359866X.2012.700045 Malkus, M., Hoyer, K., \& Sparks, D. (2015). Teaching vacancies and difficult-to-staff teaching positions in public schools. (NCES 2015065). Washington, D.C.: U.S. Department of Education.

Manuel, J. \& Hughes, J. (2006). 'It has always been my dream': Exploring pre-service teachers' motivations for choosing to teach. Teacher Development, 10(1), 5-24. https://doi.org/10.1080/13664530600587311 
Houdyshell, M.E., Teaching as a career choice: A case study on the perceptions of emerging teachers

National Education Association. (2017). 2016-17 Average Starting Teacher Salaries by State. http://www.nea.org/home/2016-2017-average-starting-teacher-salary.html

National Research Council of the National Academies. (2010). Preparing teachers. Building evidence for sound policy ( $1^{\text {st }}$ ed.). Washington, DC: The National Academies Press.

PDK Poll of the Public's Attitude Toward the Public Schools (2018).

PDK Poll of the Public's Attitude Toward the Public Schools (2015).

Partelow, L, Brown, C., \& Johnson, S. (2014). America Needs More Teachers of Color and a More Selective Teaching Profession. Retrieved from https://www.americanprogress.org/ issues/education-k-12/reports/2017/09/14/437667/america-needs-teachers-colorselective-teaching-profession

Richardson, P. W. \& Watt, H. M. (2005). 'I've decided to become a teacher': Influences on career change. Teaching and teacher education, 21(5), 475-489. https://doi.org/10.1016/j.tate.2005.03.007

Richardson, V. \& Roosevelt, D. (2004). Teacher preparation and the improvement of teacher education. In M. A. Smylie \& D. Miretzky (Eds.), Developing the Teacher Workforce (pp. 105-144). Chicago, IL: The University of Chicago Press.

Sadker, D.M. \& Zittleman, K. R. (2018). Teachers, schools, and society: A brief introduction to education. New York, NY: McGraw-Hill Education.

Stake, R.E. (2005). Qualitative case studies. In N. K. Denzin \& Y.S. Lincoln (Eds.). The SAGE Handbook of Qualitative Research (pp. 443-466). Thousand Oaks, CA: SAGE

Publications, Inc.

Stumpenhorst, J.D. (2015). Technology as a linchpin to change. The new teacher revolution: Changing education for a new generation of learners (pp. 59-72). Thousand Oaks, CA:

SAGE Publications, Inc.

Su, Z. (1997). Teaching as a profession and as a career: Minority candidates' perspectives. Teaching and Teacher Education, 13, 325-340. https://doi: 10.1016/S0742051X(96)00021-2

Su, Z., Hawkins, J. N., Huang, T., \& Zhao, Z. (2001). Choices and commitment: A comparison of teacher candidates' profiles and perspectives in China and the United States. International Review of Education, 47, 611-635. https://doi:10.1023/A:1013184026015

Sutcher, L., Darling-Hammond, L., \& Carver-Thomas, D. (2016). A coming crisis in teaching? 
Houdyshell, M.E., Teaching as a career choice: A case study on the perceptions of emerging teachers

Teacher supply, demand, and shortages in the U.S. Palo Alto, CA: Learning Policy Institute.

Tarman, B. (2012) Prospective Teachers' Beliefs and Perceptions about Teaching as a Profession, Educational Sciences: Theory \& Practice - 12(3), 1-24.

Tarpey, W. (2018). 8 Bachelor's Degree Majors with High Starting Salaries (2018). Retrieved from https://www.careerbuilder.com/advice/8-bachelors-degree-majors-with-high-startingsalaries

Watt, H. M. G. \& Richardson, P. W. (2007). Motivational factors influencing teaching as a career choice: Development and validation of the FIT-Choice scale. The Journal of Experimental Education, 75, 167-202. https://doi: 10.3200/JEXE.75.3.167-202

Wilson, S. M., Bell, C., Galosy, J. A., \& Shouse, A. W. (2004). "Them that's got shall get": Understanding teacher recruitment, induction, and retention. In M. A. Smylie \& D. Miretzky (Eds.), Developing the Teacher Workforce (pp. 145-179). Chicago, IL: The University of Chicago Press.

Yazan, B. (2015). Three approaches to case study design in Education. The Qualitative Report, 20(2), 134-152. Retrieved from https://nsuworks.nova.edu/tar/vol20/iss2/12

Yin, R.K. (2014). Case study research: Design and methods (5 ${ }^{\text {th }}$ ed.). Thousand Oaks, CA: SAGE Publications, Inc.

Younger, M., Brindley, S., Pedder, D., \& Hagger, H. (2004). Staring points: Student teachers' reasons for becoming teachers and their preconceptions of what this will mean.

European Journal of Teacher Education, 27, 245-264.
https://doi:10.1080/0261976042000290787 